\title{
Addressing sustainable ruminal methane and carbon dioxide emissions of soybean hulls by organic acid salts
}

\author{
M.M.Y. Elghandour a, A.E. Kholif ${ }^{b}$, A.Z.M. Salem ${ }^{\text {a, }}{ }^{,}$, R. Montes de Oca ${ }^{a}$, A. Barbabosa ${ }^{a}$, \\ M. Mariezcurrena ${ }^{a}$, O.A. Olafadehan ${ }^{\mathrm{c}}$ \\ a Facultad de Medicina Veterinaria y Zootecnia, Universidad Autónoma del Estado de México, Mexico \\ b Dairy Science Department, National Research Centre, 33 Bohouth St., Dokki, Giza, Egypt \\ ${ }^{\mathrm{c}}$ Department of Animal Science, University of Abuja, Abuja, Nigeria
}

\section{A R T I C L E I N F O}

\section{Article history:}

Received 20 April 2016

Received in revised form

11 June 2016

Accepted 15 June 2016

Available online 17 June 2016

\section{Keywords:}

Corn grain

Greenhouse gases emission

Organic acid salts

Rumen fermentation

Soybean hulls

\begin{abstract}
A B S T R A C T
The current study aimed to study the sustainable mitigation of methane $\left(\mathrm{CH}_{4}\right)$ and carbon dioxide $\left(\mathrm{CO}_{2}\right)$ emissions as well as ruminal fermentation kinetics by replacing dietary corn grain (CG) with soybean hulls $(\mathrm{SH})$ in the presence of organic acid salts (OAS). Three total mixed rations were prepared where CG was replaced with SH at three levels (/kg DM): $0 \mathrm{~g}$ (Control), $75 \mathrm{~g}$ (SH75) or $150 \mathrm{~g}$ (SH150). The OAS was used at three levels (dose): 0,5 and $10 \mathrm{mg} / \mathrm{g}$ DM of substrates. Increasing SH level increased $(P<0.05)$ the fractional rate of gas production (GP) and lag time. The SH75 and SH150 rations quadratically decreased $(P<0.001)$ the asymptotic $\mathrm{CO}_{2}$ production and the lag time of $\mathrm{CO}_{2}$ production. Moreover, the high level of OAS quadratically decreased $(P \leq 0.05) \mathrm{CO}_{2}$ production. The OAS inclusion increased $(P<0.05) \mathrm{CH}_{4}$ production (expressed as $\mathrm{mL} / \mathrm{g}$ incubated $\mathrm{DM}$ and $\mathrm{mL} / \mathrm{g}$ degraded $\left.\mathrm{DM}\right)$. Increasing $\mathrm{SH}$ in the rations increased $(P<0.05)$ proportional $\mathrm{CH}_{4}$ production. Inclusion of OAS also increased proportional $\mathrm{CH}_{4}$ production. Replacing corn grain with soybean hulls could be a valuable means of sustainable mitigation of $\mathrm{CH}_{4}$ and $\mathrm{CO}_{2}$ emissions and improvement of the environmental conditions as well as provision of good feedstuff for ruminant livestock due to its in vitro fermentation characteristics. The organic acid salts did not affect ruminal gas production but decreased $\mathrm{CO}_{2}$ emissions; thus its supplementation when soybean hulls replace corn grain is perhaps redundant, though may be considered as environmental friendly way of feeding livestock.
\end{abstract}

() 2016 Elsevier Ltd. All rights reserved.

\section{Introduction}

Agriculture wastes are carbohydrate-rich feeds with a large potential source of dietary energy for ruminants, but in developing countries, they always constitute environmental problems when burnt in the field, and can be used as a cleaner product of animal feed and environment (Kholif et al., 2014). However, intensive ruminant production requires high concentrate diets to assure high productivity and fast growth. Cereals, such as barley, wheat and corn, are commonly used for intensive ruminant production. However, because grain prices are rising worldwide, producers search for alternatives that can partially replace the expensive grains. Apart from being exorbitant, grains are used with some

\footnotetext{
* Corresponding author

E-mail address: asalem70@yahoo.com (A.Z.M. Salem).
}

cautions in ruminant diets because they can predispose the animals to acidosis and laminitis at a high level (Owens et al., 1998). Soybean hulls ( $\mathrm{SH}$ ) have been successfully fed as an economic substitute in the diets of ruminants (Costa et al., 2012). Because of the low energy density and fibrous nature of most unconventional ingredients which are majorly agro-industrial by-products, their inclusion in livestock diets requires supplementation with energy feed ingredients (e.g. corn grains (CG)) and additives (e.g. organic acid salts (OAS)). Though SH are readily available and inexpensive, they are fibrous; the composition ( $\mathrm{g} / \mathrm{kg} \mathrm{DM})$ is: crude protein, 116; neutral detergent fiber, 722 and acid detergent fiber, 411 (Costa et al., 2012). Replacement of energy feedstuff such as CG with SH will require some form of supplementation with OAS and acids which are used as energy additives in ruminant diets. Unconventional energy sources such as glycerol, propylene glycol, calcium propionate (Ferraro et al., 2016), or sodium propionate (Bas et al., 2000) or disodium malate or calcium malate (Mungói et al., 2012) 
have been used as ingredients of rations for ruminants. Castillo et al. (2004) suggested that the inclusion OAS can stimulate the production of propionic acid in the rumen with reduced methane $\left(\mathrm{CH}_{4}\right)$ emission by acting as a hydrogen $\left(\mathrm{H}_{2}\right)$ sink. In their experiment, Newbold et al. (2005) observed that OAS decreased methane emission by between 8 and 17\%.

Methane formation from ruminant livestock is one of the sources responsible for greenhouse gas emission causing increasing attention from animal nutritionists (Intergovernmental Panel on Climate Change, 2008). The FAO estimated $\mathrm{CH}_{4}$ production from livestock to contribute about $18 \%$ of all greenhouse gas emissions, while carbon dioxide $\left(\mathrm{CO}_{2}\right)$ accounts for about $9 \%$ emission. Besides, enteric $\mathrm{CH}_{4}$ from ruminants as a result of ruminal fermentation of feed in the rumen implies a loss of digested energy (Johnson and Johnson, 1995) depending on diet degradability and chemical composition (Hristov et al., 2013).

The in vitro gas production procedure has become a useful tool to study potential rumen degradation of ruminant feeds (Rodriguez et al., 2015; Vallejo et al., 2016). This method allows estimation of how much substrate is used to produce volatile fatty acids and the energetic value of feed as well as to determine the amount of substrate truly fermented which is converted into microbial protein (Elghandour et al., 2015a,b). The current study aimed to investigate the impact of replacing CG of diet with $\mathrm{SH}$ in the presence of fermentation modulator containing OAS on the mitigation of the ruminal $\mathrm{CH}_{4}$ and $\mathrm{CO}_{2}$ emissions and fermentation kinetics, as a clean product for the environment and animal feed.

\section{Materials and methods}

\subsection{Substrates and treatments}

Three total mixed rations were prepared where CG was replaced with SH at three levels (/kg DM): $0 \mathrm{~g}$ (Control), $75 \mathrm{~g}$ (SH75) or $150 \mathrm{~g}$ (SH150). The ingredient and chemical compositions are shown in Table 1 . The diets were supplemented with OAS as an additive containing salts of organic acids including monopropylene glycol, calcium propionate, calcium malate and other active compounds (Table 2). The additive was used at three levels: 0,5 and $10 \mathrm{mg} /$ g DM of substrates.

Table 1

Ingredients and composition of the experimental diets.

\begin{tabular}{lrrr}
\hline & Control & SH75 & SH150 \\
\hline Ingredients (g/kg DM) & & & \\
Oats straw & 249 & 248 & 248 \\
Steam rolled corn & 250 & 175 & 100 \\
Soybean hulls & 0 & 75 & 150 \\
Steam rolled barley & 250 & 250 & 250 \\
Wheat bran & 120 & 110 & 120 \\
Corn gluten feed & 30 & 30 & 30 \\
Soybean meal & 30 & 30 & 20 \\
Molasses & 70 & 80 & 80 \\
Vitamins/Minerals mixture & 1 & 2 & 2 \\
Chemical composition (g/kg DM) & & & \\
Organic matter & 964 & 968 & 958 \\
Crude protein & 130 & 117 & 130 \\
Neutral detergent fiber & 356 & 385 & 395 \\
Acid detergent fiber & 121 & 115 & 193 \\
Nonstructural carbohydrates & 454 & 442 & 415 \\
Ether extract & 24 & 24 & 18 \\
\hline
\end{tabular}

a Contained: Vitamin A (12 $000000 \mathrm{IU})$, Vitamin $\mathrm{D}_{3}$ (2 $\left.500000 \mathrm{IU}\right)$, Vitamin E (15 $000 \mathrm{IU})$, Vitamin $\mathrm{K}(2.0 \mathrm{~g})$, Vitamin $\mathrm{B}_{1}(2.25 \mathrm{~g})$, Vitamin $\mathrm{B}_{2}(7.5 \mathrm{~g})$, Vitamin $\mathrm{B}_{6}$ (3.5 g), Vitamin $B_{12}(20 \mathrm{mg})$, Pantotenic acid (12.5 g), Folic acid (1.5 g), Biotin (125 mg), Niacin (45 g), Fe (50 g), Zn (50 g), Mn (110 g), Cu (12 g), I (0.30 g), Se (200 mg), Co (0.20 g).
Table 2

Composition ( $\mathrm{g} / \mathrm{kg} \mathrm{DM}$ ) of the rumen fermentative modulator of organic acid salts.

\begin{tabular}{lcll}
\hline & ppm & Inclusion & Concentration \\
\hline Monopropylene glycol powder & 60 & 196 & 118 \\
Calcium propionate & 98 & 393 & 385 \\
Calcium malate & 60 & 371.9 & 223 \\
Silicon dioxide & 100 & 20 & 20 \\
Amino acid-chelate Zn & 26 & 8 & $2080 \mathrm{ppm}$ \\
Zinc-L-selenomethionene Se & 10 & 0.12 & $12 \mathrm{ppm}$ \\
$1,25-(\mathrm{OH})_{2}-\mathrm{D}_{3}$ & 10 & 10 & $0.1 \mathrm{ppm}$ \\
E vitamin IU/kg & 500,000 & 1 & $500 \mathrm{IU} / \mathrm{kg}$ \\
\hline
\end{tabular}

\subsection{In vitro fermentation}

Rumen inoculum was collected from a Brown Swiss cow $(450 \mathrm{~kg}$ BW) fitted with a permanent rumen cannula and fed ad libitum a formulated total mixed ration of a commercial concentrate (PURINA $^{\circledR}$, Toluca, Mexico) and alfalfa hay in the ratio of $1: 1 \mathrm{DM}$ according to NRC (2001). During collection phase, cow was offered fresh water ad libitum. Collected rumen contents were flushed with $\mathrm{CO}_{2}$, mixed and strained through four layers of cheesecloth into a flask with $\mathrm{O}_{2}$-free headspace. Samples $(0.5 \mathrm{~g})$ of each ration were weighed into $120 \mathrm{~mL}$ serum bottles with appropriate addition of OAS dose/g DM. Consequently, $10 \mathrm{~mL}$ of particle free rumen fluid was added to each bottle followed by $40 \mathrm{~mL}$ of the buffer solution of Goering and Van Soest (1970), with no trypticase added.

Three incubation runs were performed in different three weeks. Eighty one bottles (three bottles for each ration $\times$ three levels of OAS $\times$ three different runs) plus three bottles as blanks (rumen fluid only) were incubated for $72 \mathrm{~h}$. Once all bottles were filled, they were immediately closed with rubber stoppers, shaken and placed in an incubator at $39{ }^{\circ} \mathrm{C}$. The volume of produced gases was recorded at $2,4,6,8,10,12,14,16,18,24,36,48$ and $72 \mathrm{~h}$ using the Pressure Transducer Technique (Extech instruments, Waltham, USA) of Theodorou et al. (1994). Both of $\mathrm{CH}_{4}$ and $\mathrm{CO}_{2}$ productions were recorded at 2, 6, 12, 18, 24, 36, 48 and $72 \mathrm{~h}$ of incubation using Gas-Pro detector (Gas Analyzer CROWCON, Model Tetra3, Abingdon, UK). At the end of incubation at $72 \mathrm{~h}$, the fermentation process was stopped by swirling the bottles in ice. The bottles were then uncapped and the $\mathrm{pH}$ was measured using a $\mathrm{pH}$ meter (Conductronic pH15, Puebla, Mexico) and the contents of each bottle filtered under vacuum through glass crucibles (coarse porosity no. 1 , pore size $100-160 \mu \mathrm{m}$; Pyrex, Stone, UK) with a sintered filter to obtain the non-fermented residue for determination of degraded substrate after drying at $65{ }^{\circ} \mathrm{C}$ overnight.

\subsection{Chemical analyses and calculations}

Samples of the rations were analyzed for DM (\#934.01), ash (\#942.05), N (\#954.01) and ether extract (\#920.39) according to AOAC (1997), while ration's contents for neutral detergent fiber content (NDF) and acid detergent fiber (ADF) analyses were carried out using an ANKOM $^{200}$ Fiber Analyzer Unit (ANKOM Technology Corp., Macedon, NY, USA) with the use of an alpha amylase and sodium sulfite (Van Soest et al., 1991).

For estimation of GP, $\mathrm{CH}_{4}$ and $\mathrm{CO}_{2}$ kinetics, recorded gas, $\mathrm{CH}_{4}$ and $\mathrm{CO}_{2}$ volumes ( $\mathrm{mL} / \mathrm{g} \mathrm{DM}$ ) were fitted using the NLIN procedure of SAS (2000) according to France et al. (2000) model as:

$y=b \times\left[1-\mathrm{e}^{-c(t-L)}\right]$

where $y$ is the volume of $\mathrm{GP}, \mathrm{CH}_{4}$ or $\mathrm{CO}_{2}$ at time $t(\mathrm{~h}) ; b$ is the asymptotic GP, the asymptotic $\mathrm{CH}_{4}$ or the asymptotic $\mathrm{CO}_{2}(\mathrm{~mL} /$ $\mathrm{g} \mathrm{DM}) ; c$ is the fractional rate of fermentation $(/ \mathrm{h})$, and $L(\mathrm{~h})$ is the 
discrete lag time prior to when any gas, $\mathrm{CH}_{4}$ or $\mathrm{CO}_{2}$ is released.

Metabolizable energy ( $\mathrm{ME}, \mathrm{MJ} / \mathrm{kg} \mathrm{DM}$ ) and in vitro organic matter digestibility (OMD, $\mathrm{g} / \mathrm{kg} \mathrm{OM}$ ) were estimated according to Menke et al. (1979) as:

$$
\begin{aligned}
\mathrm{ME}=2.20+0.136 \mathrm{GP}(\mathrm{mL} / 0.5 \mathrm{~g} \mathrm{DM})+0.057 \mathrm{CP}(\mathrm{g} / \mathrm{kg} \mathrm{DM}) \\
\begin{aligned}
\mathrm{OMD}= & 148.8+8.89 \mathrm{GP}+4.5 \mathrm{CP}(\mathrm{g} / \mathrm{kg} \mathrm{DM}) \\
& +0.651 \mathrm{ash}(\mathrm{g} / \mathrm{kg} \mathrm{DM})
\end{aligned}
\end{aligned}
$$

where: GP is net GP in $\mathrm{mL}$ from $200 \mathrm{mg}$ of dry sample after $24 \mathrm{~h}$ of incubation.

\subsection{Statistical analyses}

Data of each of the three runs within the same sample of each of the three individual samples of rations were averaged prior to statistical analysis, then mean values of each individual sample were used as the experimental unit. Results of in vitro GP and rumen fermentation parameters were analyzed as a factorial experiment using the PROC GLM option of SAS (2000) as:

$Y_{i j k}=\mu+R_{i}+D_{j}+(R \times D)_{i j}+E_{i j k}$

where: $Y_{i j k}=$ is every observation of the $i$ th ration type $\left(R_{i}\right)$ with $j$ th OAS dose $\left(D_{j}\right) ; \mu$ is the general mean; $(R \times D)_{i j}$ is the interaction between ration type and OAS dose; $\mathrm{E}_{\mathrm{ijk}}$ is the experimental error. Linear and quadratic polynomial contrasts were used to examine responses of different $\mathrm{SH}$ containing rations to increasing addition levels of OAS. Statistical significance was declared at $P<0.05$.

\section{Results}

Fig. 1 shows the in vitro rumen gas production $(\mathrm{mL} / \mathrm{g}$ incubated DM) of three different levels of $\mathrm{SH}$ as affected by different levels of OAS. Level of SH (ration) and level of OAS (dose) respectively had no effect $(P>0.05)$ on asymptotic GP, but it was affected $(P=0.027)$ by ration $\times$ dose interaction. Fractional rate of GP $(P<0.001)$ and lag time $(P<0.005)$ increased linearly with increasing level of SH. Except for $c$ which was quadratically $(P<0.01)$ affected, $b$ and GP were not affected $(P>0.05)$ by level of OAS (dose) inclusion (Table 3).

Fig. 2 shows the in vitro rumen $\mathrm{CH}_{4}$ production $(\mathrm{mL} / \mathrm{g}$ incubated DM) of three different levels of SH as affected by different levels of OAS. Ration type had no effect $(P>0.05)$ on the asymptotic $\mathrm{CH}_{4}$ production and rate of $\mathrm{CH}_{4}$ production (Table 3 ).

Ration type quadratically affected $(P<0.05)$ the asymptotic $\mathrm{CO}_{2}$ production, the lag time of $\mathrm{CO}_{2}$ production and the rate of $\mathrm{CO}_{2}$ production, but the SH75 and SH150 rations decreased (linear effect, $P=0.011$; quadratic effect, $P=0.006$ ) lag time of $\mathrm{CO}_{2}$ production compared with the control ration. On the other hand, OAS inclusion had no effect $(P>0.05)$ on the asymptotic $\mathrm{CO}_{2}$ production and the rate of $\mathrm{CO}_{2}$ production; however, the dose of $10 \mathrm{mg} / \mathrm{g} \mathrm{DM}$ quadratically increased $(P=0.004)$ the lag time of $\mathrm{CO}_{2}$ production. The in vitro $\mathrm{CO}_{2}$ production $(\mathrm{mL} / \mathrm{g}$ incubated $\mathrm{DM})$ of three different levels of $\mathrm{SH}$ as affected by different levels of OAS is shown in Fig. 3.

At $6 \mathrm{~h}$ of incubation, SH75 and SH150 increased (linear effect, $P=0.027) \mathrm{CH}_{4}$ production $(\mathrm{mL} / \mathrm{g}$ incubated $\mathrm{DM}$ ) compared with the control ration, but there was no effect $(P>0.05)$ of ration type at 24 and $48 \mathrm{~h}$ of incubations. However, OAS inclusion at both treatment levels increased (quadratic effect, $P \leq 0.01$ ) $\mathrm{CH}_{4}$ production (as $\mathrm{mL} / \mathrm{g}$ incubated DM) at 24 and $48 \mathrm{~h}$ of incubation. Moreover, $\mathrm{CH}_{4}$ production (as $\mathrm{mL} / \mathrm{g}$ degraded $\mathrm{DM}$ ) was increased (linear and quadratic effect, $P \leq 0.015$ ) with the inclusion of OAS at 5 and $10 \mathrm{mg} / \mathrm{g} D M$ at
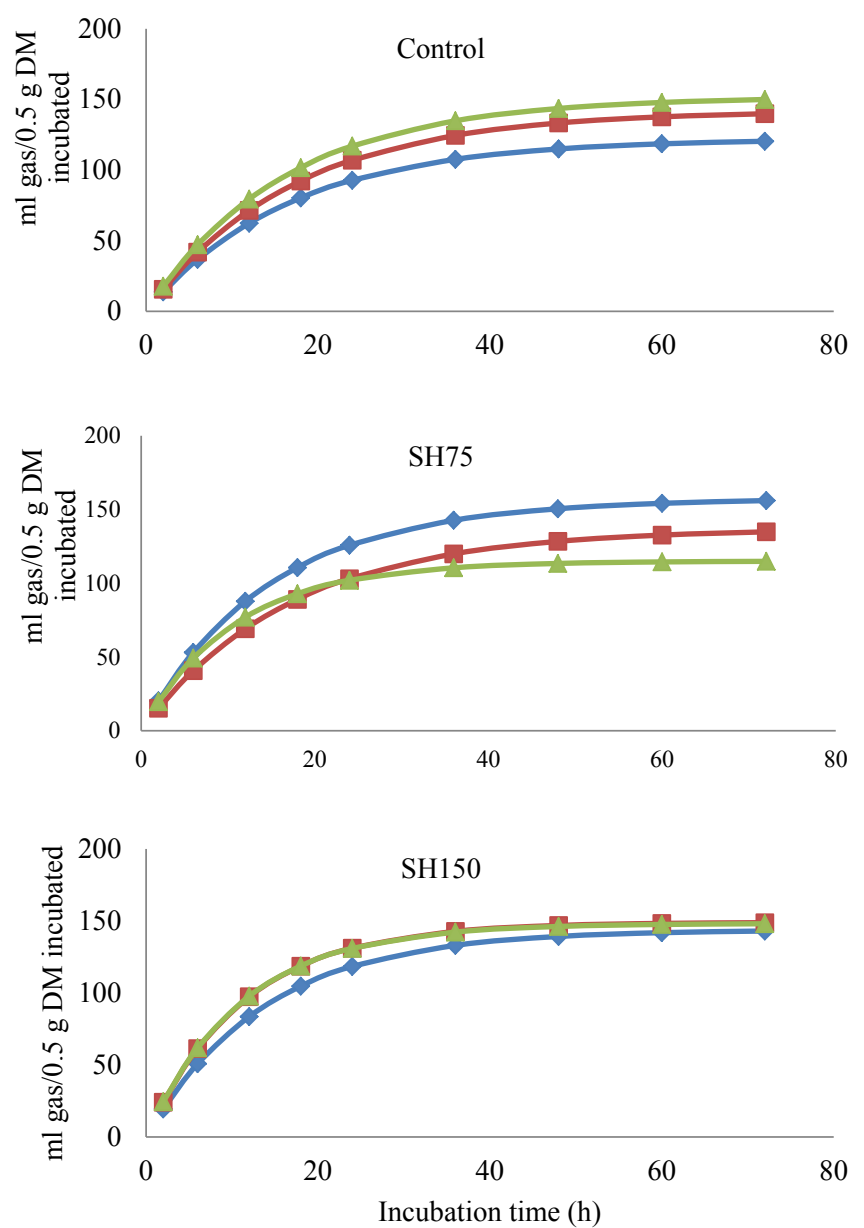

Fig. 1. In vitro rumen gas production $(\mathrm{mL} / 0.5 \mathrm{~g}$ incubated $\mathrm{DM})$ of three different levels of soybean hulls ( $\mathrm{SH}$ ) as affected by different levels of organic acid salts at $0(--), 5$ $(--)$, and $10\left(-\Delta_{-}\right) \mathrm{mg} / \mathrm{g} \mathrm{DM}$ of the ration. Control: corn grain was replaced with soybean hulls at $0 \mathrm{~g} / \mathrm{kg} \mathrm{DM}$; SH75: soybean hulls were included at $75 \mathrm{~g} / \mathrm{kg} \mathrm{DM}$ of total mixed ration; SH150: soybean hulls were included at $150 \mathrm{~g} / \mathrm{kg}$ DM of total mixed ration.

all hours. The proportional $\mathrm{CH}_{4}$ production at 24 and $48 \mathrm{~h}$ of incubation was affected (quadratic effect, $P \leq 0.009$ ) by the ration type; increasing the percent of $\mathrm{SH}$ in the rations resulted in increased proportional $\mathrm{CH}_{4}$ production. At 6 and $48 \mathrm{~h}$ of incubations, the inclusion of OAS at the both treatment levels increased (linear effect, $P \leq 0.017$ ) proportional $\mathrm{CH}_{4}$ production but at both 24 and $48 \mathrm{~h}$, both treatment levels had quadratic effect $(P \leq 0.005)$ on proportional $\mathrm{CH}_{4}$ production (Table 4). On the contrary, both of ration type and OAS inclusion had no effect $(P>0.05)$ on $\mathrm{CO}_{2}$ production $(\mathrm{mL} / \mathrm{g}$ incubated $\mathrm{DM}$ or $\mathrm{mL} / \mathrm{g}$ degraded DM) and proportional $\mathrm{CO}_{2}$ production (Table 4).

Ration effects on $\mathrm{pH}$ and DM degradability (DMD; $P<0.001$ ), $\mathrm{ME}$, and OMD were linear. Effects of ration and ration $\times$ OAS dose interactions were not significant for these parameters (Table 5).

\section{Discussion}

The in vitro GP technique has been used as a measure of ruminal degradation of feeds (Salem et al., 2014). The GP is generally a good indicator of digestibility, fermentability and microbial protein production. Higher gas values indicate a better nutrient availability for rumen micro-organisms (Elghandour et al., 2015a,b). The generally high fractional rate of GP shows that the diets were highly 
Table 3

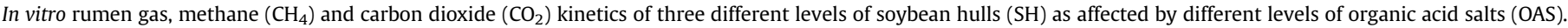

\begin{tabular}{|c|c|c|c|c|c|c|c|c|c|c|}
\hline \multirow[t]{2}{*}{ Ration $^{\mathrm{a}}$} & \multirow[t]{2}{*}{ OAS (mg/g DM) } & \multicolumn{3}{|c|}{ Gas production $(\mathrm{mL} / 0.5 \mathrm{~g} \mathrm{DM})^{\mathrm{b}}$} & \multicolumn{3}{|c|}{$\mathrm{CH}_{4}$ production $(\mathrm{mL} / \mathrm{g} \mathrm{DM})^{\mathrm{c}}$} & \multicolumn{3}{|c|}{$\mathrm{CO}_{2}$ production $(\mathrm{mL} / \mathrm{g} \mathrm{DM})^{\mathrm{d}}$} \\
\hline & & $b$ & $c$ & $L$ & $b$ & $c$ & $L$ & $b$ & $c$ & $L$ \\
\hline \multirow[t]{3}{*}{ Control } & 0 & 122 & 0.06 & 1.35 & 37.0 & 0.021 & 4.38 & 106.7 & 0.010 & 4.45 \\
\hline & 5 & 142 & 0.06 & 1.1 & 66.8 & 0.028 & 8.61 & 78.3 & 0.015 & 4.16 \\
\hline & 10 & 152 & 0.06 & 1.61 & 79.9 & 0.022 & 9.50 & 117.5 & 0.005 & 5.62 \\
\hline \multirow[t]{3}{*}{ SH75 } & 0 & 158 & 0.07 & 1.84 & 90.7 & 0.013 & 9.62 & 34.8 & 0.041 & 3.22 \\
\hline & 5 & 137 & 0.06 & 1.69 & 80.4 & 0.020 & 6.24 & 31.1 & 0.026 & 4.73 \\
\hline & 10 & 115 & 0.1 & 1.76 & 106.5 & 0.014 & 6.34 & 35.1 & 0.046 & 6.99 \\
\hline \multirow{3}{*}{ SH150 } & 0 & 144 & 0.07 & 1.69 & 49.0 & 0.017 & 10.05 & 73.4 & 0.003 & 2.02 \\
\hline & 5 & 149 & 0.09 & 1.86 & 114.2 & 0.012 & 9.10 & 96.3 & 0.001 & 1.84 \\
\hline & 10 & 148 & 0.09 & 1.73 & 107.9 & 0.014 & 8.10 & 126.5 & 0.005 & 2.84 \\
\hline Pooled S & & 9.8 & 0.007 & 0.153 & 17.32 & 0.0055 & 1.112 & 15.51 & 0.0087 & 0.746 \\
\hline \multicolumn{11}{|c|}{ Ration effect } \\
\hline Linear & & 0.317 & 0.001 & 0.005 & 0.054 & 0.062 & 0.098 & 0.872 & 0.339 & 0.006 \\
\hline Quadr & & 0.390 & 0.640 & 0.070 & 0.189 & 0.399 & 0.271 & $<0.001$ & $<0.001$ & 0.011 \\
\hline \multicolumn{11}{|c|}{ Dose effect } \\
\hline Linear & & 0.860 & 0.800 & 0.540 & 0.061 & 0.486 & 0.970 & 0.811 & 0.571 & 0.581 \\
\hline Quadr & & 0.610 & 0.010 & 0.310 & 0.056 & 0.666 & 0.979 & 0.051 & 0.690 & 0.004 \\
\hline Ration $\times$ & & 0.027 & 0.095 & 0.307 & 0.344 & 0.814 & 0.007 & 0.334 & 0.517 & 0.342 \\
\hline
\end{tabular}

a SH75, soybean hulls were included at $75 \mathrm{~g} / \mathrm{kg}$ DM of total mixed ration; SH150, soybean hulls were included at $150 \mathrm{~g} / \mathrm{kg}$ DM of total mixed ration.

b $b$ is the asymptotic gas production $(\mathrm{mL} / 0.5 \mathrm{~g} \mathrm{DM}) ; c$ is the rate of gas production $(/ \mathrm{h})$; $L$ is the initial delay before gas production begins (h).

${ }^{c} b$ is the asymptotic methane production ( $\left.\mathrm{mL} / \mathrm{g} \mathrm{DM}\right) ; c$ is the rate of methane production $(/ \mathrm{h}) ; L$ is the initial delay before methane production begins (h).

${ }^{d} b$ is the asymptotic carbon dioxide production ( $\left.\mathrm{mL} / \mathrm{g} \mathrm{DM}\right) ; c$ is the rate of carbon dioxide production (/h); $L$ is the initial delay before carbon dioxide production begins (h).

e SEM standard error of the mean.

digestible because the rate at which a feed or its chemical constituents are digested in the rumen is as important as the extent of digestion. The values obtained were within the range of 0.056- $-0.17 \mathrm{mg} / \mathrm{g}$ DM reported for CG and canola (Getachew et al., 2004). The increasing fractional rate of GP with increased level of replacement of $\mathrm{CG}$ with $\mathrm{SH}$ is indicative of enhanced degradability or fermentability of the diets. The rate at which different chemical constituents are fermented is a reflection of microbial growth and accessibility of the feed to microbial enzymes (Getachew et al., 2004). It appears that partial replacement of CG with SH has the propensity of improve feed intake and consequently the performance of ruminants. This conjecture is supported by the assertion of Khazaal et al. (1996) who stated that the intake of a feed is mostly explained by the fractional rate of GP which affects the rate of passage of the feed through the rumen. Fractional rate of GP reduced from 0 to $5 \mathrm{mg}$ OAS/g DM supplementation and increased as the level of OAS was increased to $10 \mathrm{mg} / \mathrm{g}$ DM. Higher fractional rate of GP at $10 \mathrm{mg}$ OAS/g DM supplementation depicts enhanced fermentation and degradation. Using three energy additives, glycerol, propylene glycol and molasses, Ferraro et al. (2016) attributed higher fractional rate of GP of molasses to its greater fermentability. As earlier opined, supplementation with $10 \mathrm{mg}$ OAS/g DM has the tendency to enhance voluntary feed intake and performance. The values obtained for the rate of GP are similar to those reported by Ferraro et al. (2016). The delay in the onset of GP and thus a longer lag time as SH replaced CG suggests that feeding of SH delayed microbial adaptation to the diets. According to Ferraro et al. (2016) continuous feeding of an energy additive in the sheep diet induces microbial adaptation and shortens the lag phase. Similarly, lower lag phase of the control diet is suggestive of its availability to provide a greater proportion of nutrients. The increasing GP with increased level of replacement of CG with $\mathrm{SH}$ indicates that $\mathrm{SH}$ contained a significant amount of rapidly fermentable carbohydrate. Rapidly fermentable carbohydrate has been reported to increase GP (Elghandour et al., 2015a,b). Furthermore, increased GP with CG replacement likely promoted higher nutrient availability to rumen micro-organisms, especially available N (Guerrero et al., 2012). Ration $\times$ dose interaction indicates a synergy between levels of replacement of CG with SH and rate of OAS on asymptotic GP.
During ruminal fermentation process, many gases are produced within the rumen mainly consisting of $\mathrm{H}_{2}, \mathrm{CO}_{2}$, and $\mathrm{CH}_{4}$. In the present study, replacing $\mathrm{CG}$ with $\mathrm{SH}$ decreased $\mathrm{CO}_{2}$ production, which is very important from environmental view, as the $\mathrm{CO}_{2}$ and $\mathrm{CH}_{4}$ have direct global warming effects. Increasing fibers and decreasing nonstructural carbohydrates in the rations containing $\mathrm{SH}$ may be the main reason. Increasing cell wall content may reduce the microbial activities, causing a lowered $\mathrm{CO}_{2}$ production and decreasing lag time of $\mathrm{CO}_{2}$ production. Almost no published reports are available in the literature on the effect of replacing CG with $\mathrm{SH}$ in diets on $\mathrm{CO}_{2}$ production; therefore, the present results could not be compared.

Ration type had no effect on $\mathrm{CH}_{4}$ production, the rate of production and lag time of production. Similarly, the ration type $\times$ OAS dose interaction had no effect on $\mathrm{CO}_{2}$ production. The reason for lack of effect of level of $\mathrm{SH}$ and OAS on mitigation of $\mathrm{CH}_{4}$ emission is unknown because it was expected that the pronounced increase in GP with $\mathrm{SH}$ inclusion should be accompanied by marked changes in both $\mathrm{CH}_{4}$ mitigation and $\mathrm{CO}_{2}$ emissions. Lack of response of $\mathrm{CH}_{4}$ mitigation to both OAS dose and ration type $\times$ OAS dose interaction may be attributed to non-significant effects of these two factors on GP. However, at some hours of incubation, OAS increased $\mathrm{CH}_{4}$ production. The present results of $\mathrm{CH}_{4}$ production are in contrast to most of published reports. In their review, Sahoo and Jena (2014) reported that OAS has the ability to decrease methanogenesis by 'sinking' $\mathrm{H}_{2}$ during their conversion to propionate (Newbold and Rode, 2006). Increasing $\mathrm{H}_{2}$ removal stimulates cellulolytic bacteria resulting in increased fibers digestion. The different responses reported in the present study and the previous ones may be due to the level and nature of the OAS (i.e., the concentration of each component of the product). The OAS preparation, in the current study, included monopropylene glycol, calcium propionate, calcium malate and other active compounds. The response to the OAS is specific for each acid (Strauss and Hayler, 2001); for example, Gram positive bacteria are sensitive to long chain acids, whereas Gram negative bacteria are only sensitive to acids with less than eight carbon atoms (Partanen, 2001).

The OAS at the low level increased the lag time of $\mathrm{CH}_{4}$ production while the high level decreased it implying that the 

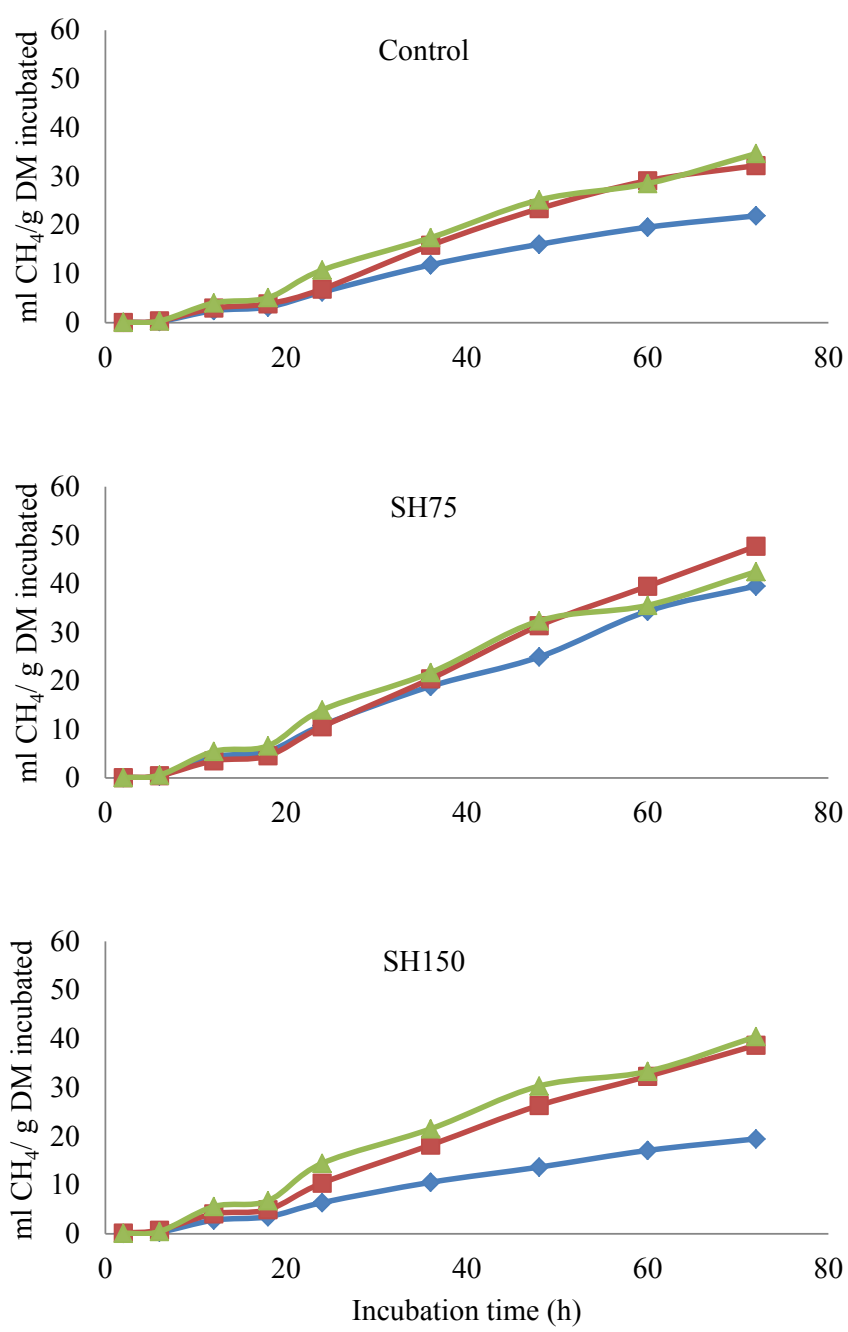

Fig. 2. In vitro methane production ( $\mathrm{mL} / \mathrm{g}$ incubated $\mathrm{DM})$ of three different levels of soybean hulls $(\mathrm{SH})$ as affected by different levels of organic acid salts at $0(-\downarrow-), 5$ $\left(-{ }_{-}\right)$, and $10\left(-\Delta_{-}\right) \mathrm{mg} / \mathrm{g} \mathrm{DM}$ of the ration. Control: corn grain was replaced with soybean hulls at $0 \mathrm{~g} / \mathrm{kg} \mathrm{DM}$; SH75: soybean hulls were included at $75 \mathrm{~g} / \mathrm{kg}$ DM of total mixed ration; SH150: soybean hulls were included at $150 \mathrm{~g} / \mathrm{kg}$ DM of total mixed ration.

response of lag time of $\mathrm{CH}_{4}$ production to the inclusion of OAS is dose dependent. The delay in the onset of $\mathrm{CH}_{4}$ production and thus a longer lag time with the inclusion of OAS suggests delayed adaptation of methanogenic archaea and bacteria to the OAS.

The decline in ruminal $\mathrm{pH}$ and rising of OMD with increasing level of SH confirm the earlier assertion that replacement of CG with $\mathrm{SH}$ diets improved the availability of readily fermentable carbohydrate which was rapidly degraded to produce volatile fatty acids. Positive correlations between readily fermentable carbohydrate and $\mathrm{pH}$ (Walsh et al., 2009) and $\mathrm{pH}$ and volatile fatty acids (Ramos et al., 2009) have been documented. Generally, dietary carbohydrates are fermented to short chain fatty acids and gases mainly $\mathrm{CO}_{2}$ and $\mathrm{CH}_{4}$ (Blümmel and Ørskov, 1993). It has been suggested that GP at $24 \mathrm{~h}$ is proportional to the amount of actually digested carbohydrates at maintenance ME intake, and is highly correlated to the ME content of feedstuffs (Giger-Riverdan et al., 2000). In the current study, ME is positively correlated to gas yield, which equally increased as the level of CG replacement with $\mathrm{SH}$ increased. Increased replacement level of SH for CG resulted in increased ME values. This is possibly due to increased OMD and
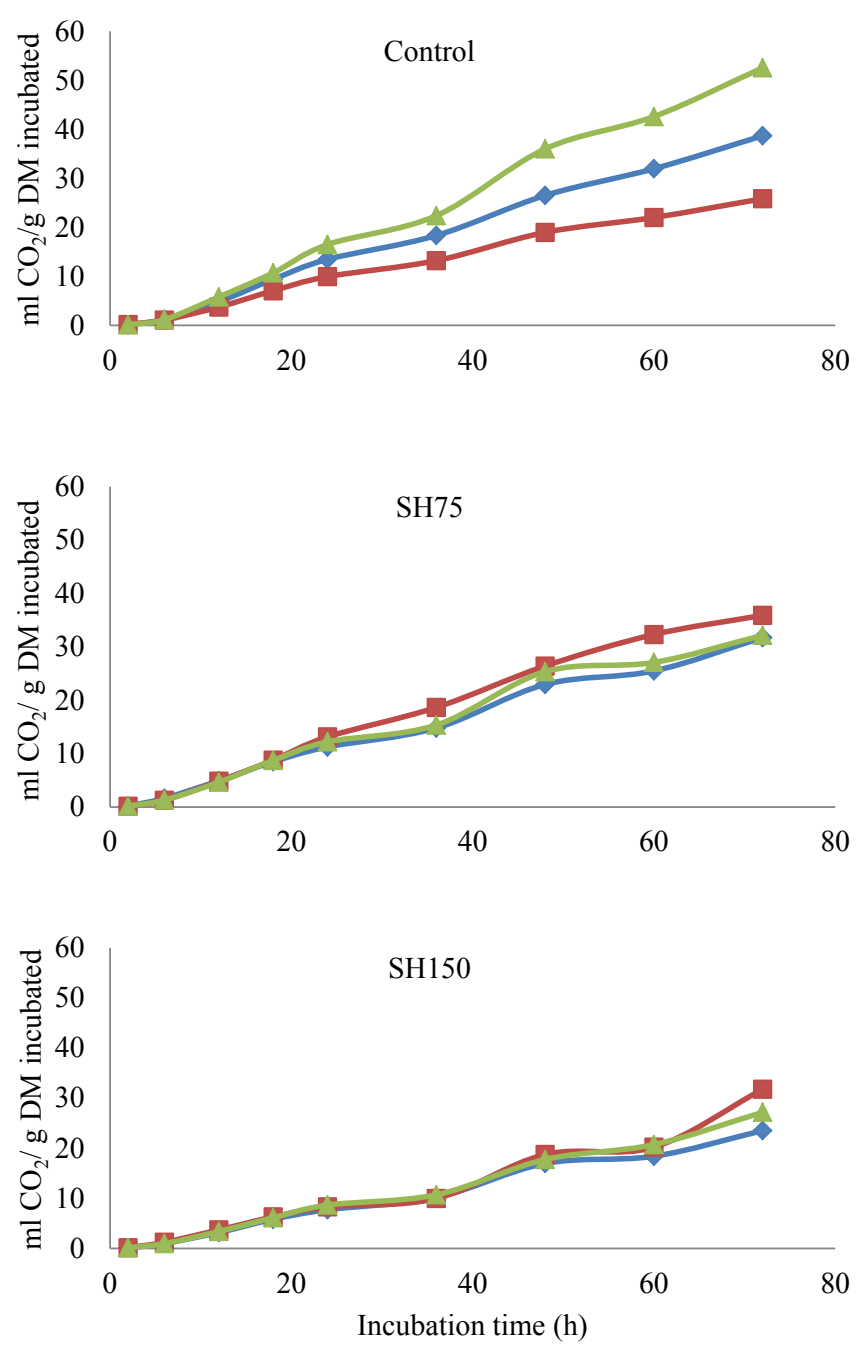

Fig. 3. In vitro carbon dioxide production ( $\mathrm{mL} / \mathrm{g}$ incubated $\mathrm{DM})$ of three different levels of soybean hulls ( $\mathrm{SH}$ ) as affected by different levels of organic acid salts at $0(-\downarrow-), 5$ $(-\square-)$, and $10\left(-\triangle_{-}\right) \mathrm{mg} / \mathrm{g} \mathrm{DM}$ of the ration. Control: corn grain was replaced with soybean hulls at $0 \mathrm{~g} / \mathrm{kg} \mathrm{DM}$; SH75: soybean hulls were included at $75 \mathrm{~g} / \mathrm{kg} \mathrm{DM}$ of total mixed ration; SH150: soybean hulls were included at $150 \mathrm{~g} / \mathrm{kg}$ DM of total mixed ration.

availability of fermentable carbohydrate and N. Differences in ME among feeds have been ascribed to variation in fermentable carbohydrates and available N among them (Guerrero et al., 2012). Linear increase in OMD with increasing replacement of CG by SH suggests that more nutrients, particularly $\mathrm{N}$, were made available to facilitate microbial degradation (Akinfemi et al., 2009). The combination of GP measurements with the concomitant quantification of the truly degraded substrate provides important information about partitioning of fermentation products. The result suggests greater fermentability of $\mathrm{SH}$ relative to $\mathrm{CG}$ which resulted in increased nutrient availability for microbial biomass production. Similarly, increasing ME with increasing SH level must have made more energy available for microbial protein production. Linear decline in in vitro DMD with increasing $\mathrm{SH}$ level needs further investigation because in vitro DMD was expected to increase with SH level, since SH appears to be more degraded than CG. This is based on increasing rate of GP and GP as the level of replacement of CG with SH level increased in the diets. In vitro DMD has reported to be positively correlated with rate of GP and GP (Akinfemi et al., 2009). 


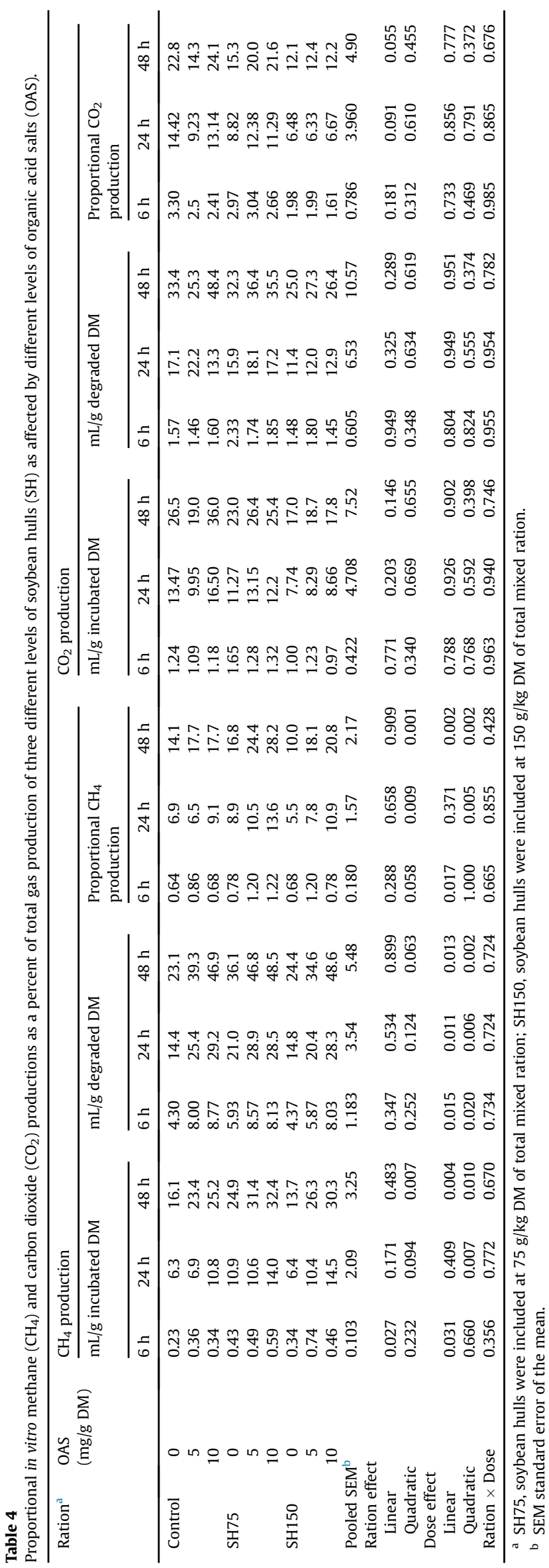

Table 5

In vitro rumen fermentation profile $e^{\mathrm{a}}$ of three different levels of soybean hulls ( $\mathrm{SH}$ ) as affected by different levels of organic acid salts (OAS).

\begin{tabular}{|c|c|c|c|c|c|}
\hline Ration $^{\mathrm{b}}$ & $\mathrm{OAS}(\mathrm{mg} / \mathrm{g} \mathrm{DM})$ & $\mathrm{pH}$ & $\mathrm{ME}$ & DMD & OMD \\
\hline \multirow[t]{3}{*}{ Control } & 0 & 6.27 & 5.41 & 824.2 & 372.5 \\
\hline & 5 & 6.53 & 5.80 & 755.3 & 397.7 \\
\hline & 10 & 6.14 & 6.07 & 741.5 & 415.7 \\
\hline \multirow[t]{3}{*}{ SH75 } & 0 & 5.97 & 6.32 & 712 & 432.2 \\
\hline & 5 & 6.06 & 5.71 & 741.5 & 391.8 \\
\hline & 10 & 6.01 & 5.68 & 717.1 & 390 \\
\hline \multirow[t]{3}{*}{ SH150 } & 0 & 5.39 & 6.12 & 679 & 419.1 \\
\hline & 5 & 5.34 & 6.47 & 692.1 & 441.7 \\
\hline & 10 & 5.54 & 6.47 & 676.9 & 441.4 \\
\hline Pooled SE & & 0.162 & 0.279 & 22.18 & 18.23 \\
\hline \multicolumn{6}{|c|}{ Ration effect } \\
\hline \multicolumn{2}{|l|}{ Linear } & $<0.001$ & 0.018 & $<0.001$ & 0.018 \\
\hline Quadra & & 0.226 & 0.443 & 0.771 & 0.447 \\
\hline \multicolumn{6}{|c|}{ Dose effect } \\
\hline \multicolumn{2}{|l|}{ Linear } & 0.465 & 0.870 & 0.633 & 0.871 \\
\hline \multicolumn{2}{|c|}{ Quadratic } & 0.800 & 0.622 & 0.173 & 0.622 \\
\hline \multicolumn{2}{|c|}{ Ration $\times$ Dose } & 0.528 & 0.186 & 0.181 & 0.185 \\
\hline
\end{tabular}

a DMD is the DM degraded substrate ( $\mathrm{mg} / \mathrm{g} \mathrm{DM})$; ME is the metabolizable energy $(\mathrm{MJ} / \mathrm{kg} \mathrm{DM}) ;$ OMD is the in vitro organic matter digestibility (mg/g DM).

b SH75, soybean hulls were included at $75 \mathrm{~g} / \mathrm{kg}$ DM of total mixed ration; SH150, soybean hulls were included at $150 \mathrm{~g} / \mathrm{kg}$ DM of total mixed ration.

${ }^{c}$ SEM standard error of the mean.

\section{Conclusions}

The organic acid salts had no effect on ruminal gases and thus its supplementation when soybean hulls replace corn grain may be redundant. Lack of soybean hulls $\times$ organic acid salts interaction on the ruminal fermentation indicates absence of synergy between the two factors in enhancing ruminal fermentation. Replacing dietary corn grain with soybean hulls could be a valuable means of sustainable mitigation of animal ruminal gases (i.e., $\mathrm{CH}_{4}$ and $\mathrm{CO}_{2}$ ) production and improvement of the environmental conditions. Corn grain can therefore be replaced with soybean hulls up to $150 \mathrm{~g} / \mathrm{kg}$ DM without adversely affecting rumen fermentation but preventing environmental degradation due to reduction in $\mathrm{CH}_{4}$ and $\mathrm{CO}_{2}$ emissions. Soybean hulls can be used as a good cleaner product for the environment and feedstuff for ruminant livestock to control the environmental contamination by ruminal gases due to its anaerobic in vitro fermentation characteristics. Further research should, however, be conducted to establish the efficacy of replacement of corn grain with soybean hulls in in vivo trials.

\section{Conflict of interest}

None.

\section{References}

Akinfemi, A., Adesanya, A.O., Aya, V.E., 2009. Use of an in vitro gas production technique to evaluate some Nigerian feedstuffs. Am. Eurasian J. Sci. Res. 4 (4), $240-245$.

AOAC., 1997. Official Methods of Analysis, sixteenth ed. Association of Official Analytical Chemists, Arlington, VA, USA.

Bas, P. Berthelot, V., Duvaux-Ponter, C., Sauvant, D., Schmidely, P., 2000. Effect of dietary propionate on fatty acid composition of lamb adipose tissues. Cah. Options. Méditerr 52, 133-135.

Blümmel, M., Ørskov, E.R. 1993. Comparison of in vitro gas production and nylon bag degradability of roughages in predicting feed intake in cattle. Anim. Feed Sci. Technol. 40, 109-119.

Castillo, C., Benedito, J.L., Méndez, J., Pereira, V., López-Alonso, M., Miranda, M., Hernández, J., 2004. Organic acids as a substitute for monensin in diets for beef cattle. Anim. Feed Sci. Technol. 115, 101-116.

Costa, S.B.M., Ferreira, M.A., Pessoa, R.A.S., Batista, A.M.V., Ramos, A.O., da Conceição, M.G., Gomes, L.H.S., 2012. Tifton hay, soybean hulls, and whole cottonseed as fiber source in spineless cactus diets for sheep. Trop. Anim. Health Prod. 44, 1993-2000.

Elghandour, M.M.Y., Kholif, A.E., Bastida, A.Z., Martínez, D.L.P., Salem, A.Z.M., 2015a. 
In vitro gas production of five rations of different maize silage and concentrate ratios influenced by increasing levels of chemically characterized extract of Salix babylonica. Turk. J. Vet. Anim. Sci. 39 (2), 186-194.

Elghandour, M.M.Y., Kholif, A.E., Marquez-Molina, O., Vazquez-Armijo, J.F., Puniya, A.K., Salem, A.Z.M., 2015b. Influence of individual or mixed cellulase and xylanase mixture on in vitro rumen gas production kinetics of total mixed rations with different maize silage and concentrate ratios. Turk. J. Vet. Anim. Sci. 39 (4), 435-442.

Ferraro, S.M., Mendoza, G.D., Miranda, L.A., Gutiérrez, C.G. 2016. In vitro ruminal fermentation of glycerol, propylene glycol and molasses combined with forages and their effect on glucose and insulin blood plasma concentrations after an oral drench in sheep. Anim. Feed Sci. Technol. 213, 74-80.

France, J., Dijkstra, J., Dhanoa, M.S., Lopez, S., Bannink, A., 2000. Estimating the extent of degradation of ruminant feeds from a description of their gas production profiles observed in vitro: derivation of models and other mathematical considerations. Br. J. Nutr. 83, 143-150.

Getachew, G., DePeters, E.J., Robinson, P.H., 2004. In vitro gas production provides effective method for assessing ruminant feeds. Calif. Agric. 58, 1-12.

Giger-Riverdan, S.C., Maarouffi, C., Bontems, V., Jousse, C., 2000. Interest and limits of the HFT method to evaluate the energy value of compound feeds for small ruminants. Cah. Options Méditerr 52, 39-42.

Goering, M.K., Van Soest, P.J., 1970. Forage Fiber Analysis (Apparatus, Reagents, Procedures and Some Applications). In: Agriculture Handbook, No 379. Agricultural Research Service, USDA, Washington, DC.

Guerrero, M., Cerrillo-Soto, M.A., Ramírez, R.G., Salem, A.Z.M., González, H., JuárezReyes, A.S., 2012. Influence of polyethylene glycol on in vitro gas production proflles and microbial protein synthesis of some shrub species. Anim. Feed Sci. Technol. 176, 32-39.

Hristov, A.N., Oh, J., Firkins, J.L., Dijkstra, J., Kebreab, E., Waghorn, G., Makkar, H.P.S., Adesogan, A., Yang, W., Lee, C., Gerber, P.J., Henderson, B., Tricarico, J., 2013. Mitigation of methane and nitrous oxide emissions from animal operations: I. A review of enteric methane mitigation options. J. Anim. Sci. 91, 5045-5069.

Intergovernmental Panel on Climate Change, 2008. Climate Change, 2007. Synthesis Report. Contribution of Working Group I, II, and III to the Fourth Assessment Report of the Intergovernmental Panel on Climate Change. IPCC, Geneva, Switzerland.

Johnson, K.A., Johnson, D.E., 1995. Methane emissions from cattle. J. Anim. Sci. 73 (8), 2483-2492.

Khazaal, K.A., Parissi, Z., Tsiouvaras, C., Nastis, A., Ørskov, E.R., 1996. Assessment of phenolics-related antinutritive levels using the in vitro gas production technique: a comparison between different types of polyvinylpyrrolidone or polyethylene glycol. J. Sci. Food Agric. 71, 405-414.

Kholif, A.E., Khattab, H.M., El-Shewy, A.A., Salem, A.Z.M., Kholif, A.M., ElSayed, M.M., Gado, H.M., Mariezcurrena, M.D., 2014. Nutrient digestibility, ruminal fermentation activities, serum parameters and milk production and composition of lactating goats fed diets containing rice straw treated with Pleurotus ostreatus. Asian-Australa. J. Anim. Sci. 27 (3), 357-364.

Menke, K.H., Raab, L., Salewski, A., Steingass, H., Fritz, D., Schneider, W., 1979. The estimation of the digestibility and metabolizable energy content of ruminant feedstuffs from the gas production when they are incubated with rumen liquor in vitro. J. Agr. Sci. 92, 217-222.

Mungói, M., Flores, C., Casals, R., Caja, G., 2012. Effect of malate and starch source on digestibility and nutrient balance of growing-fattening lambs. Anim. Feed Sci. Technol. 174, 154-162.

Newbold, C.J., Lopez, S., Nelson, N., Ouda, J.O., Wallace, R.J., Moss, A.R., 2005. Propionate precursors and other metabolic intermediates as possible alternative electron acceptors to methanogenesis in ruminal fermentation in vitro. Br. J. Nutr. 94, 27-35.

Newbold, C.J., Rode, L.M., 2006. Dietary additives to control methanogenesis in the rumen. Int. Congr. Ser. 1293, 138-147.

NRC, 2001. Nutrient Requirements of Dairy Cattle, 7th revised ed. National Academy Press, Washington, DC, USA.

Owens, F.N., Secrist, D.S., Hill, W.J., Gill, D.R., 1998. Acidosis in cattle: a review. J. Anim. Sci. 76, 275-286.

Partanen, K., 2001. Organic acids - their efficacy and modes of action in pigs. In: Piva, A., Bach Knudsen, K.E., Lindberg, J.E. (Eds.), Gut Environment of Pigs. Nottingham University Press, Nottingham, UK, pp. 201-218.

Ramos, S., Tejido, M.L., Martínez, M.E., Ranilla, M.J., Carro, M.D., 2009. Microbial protein synthesis, ruminal digestion, microbial populations, and nitrogenbalance in sheep fed diets varying in forage-to-concentrate ratio and type of forage. J. Anim. Sci. 87, 2924-2934.

Rodriguez, M.P., Mariezcurrena, M.D., Mariezcurrena, M.A., Lagunas, B.C., Elghandour, M.M.Y., Kholif, A.M., Kholif, A.E., Almaráz, E.M., Salem, A.Z.M., 2015 Influence of live cells or cells extract of Saccharomyces cerevisiae on in vitro gas production of a total mixed ration. Ital. J. Anim. Sci. 14 (4), 590-590.

Sahoo, A., Jena, B., 2014. Organic acids as rumen modifiers. Int. J. Sci. Res. 3 (11), $2262-2266$.

Salem, A.Z.M., Ryena, A.G., Elghandour, M.M.Y., Camacho, L.M., Kholif, A.E., Salazar, M.C., Domínguez, I.A., Jiménez, R.M., Almaraz, E.M., Martínez, A.G.L., Mariezcurrena, M.A., 2014. Influence of Salix babylonica extract in combination or not with increasing levels of minerals mixture on in vitro rumen gas production kinetics of a total mixed ration. Ital. J. Anim. Sci. 13 (4), 873-879.

SAS, 2000. Statistical Analysis System. In: User's Guide: Statistics. SAS Institute Inc, Cary NC, USA.

Strauss, G., Hayler, T., 2001. Effects of organic acids on microorganisms. Kraftfutter 4, 147-151.

Theodorou, M.K., Williams, B.A., Dhanoa, M.S., McAllan, A.B., France, J., 1994. A simple gas production method using a pressure transducer to determine the fermentation kinetics of ruminant feeds. Anim. Feed Sci. Technol. 48, 185-197.

Vallejo, L.H., Salem, A.Z.M., Kholif, A.E., Elghangour, M.M.M., Fajardo, R.C., Rivero, N. Bastida, A.Z., Mariezcurrena, M.D. 2016. Influence of cellulase or xylanase on the in vitro rumen gas production and fermentation of corn stover. Indian J. Anim. Sci. 86 (1), 70-74.

Van Soest, P.J., Robertson, J.B., Lewis, B.A., 1991. Methods for dietary fibre, neutral detergent fibre, and non-starch carbohydrates in relation to animal nutrition. J. Dairy Sci. 74, 3583-3597.

Walsh, K., O'Kiely, P., Taweel, H.Z., McGee, M., Moloney, A.P., Boland, T.M., 2009 Intake, digestibility and rumen characteristics in cattle offered whole-crop wheat or barley silages of contrasting grain to straw ratios. Anim. Feed Sci. Technol. 148, 192-213. 